\title{
PROFESORUL RĂZVAN GIVULESCU LA 80 DE ANI
}

În 15 septembrie 1920, la Viena, s-a născut cel care avea să devină profesorul universitar Răzvan Givulescu, din părinții Cornel Givulescu şi Hermina Givulescu (născută Reinhardt), aflați atunci la studii în capitala austriacă.

Tatăl (Cornel Givulescu) a studiat la Institut für Musikwissenschaft între 1920-1923. Fiind nevoit să abandoneze studiile muzicale, avea să ajungă profesor de muzică la Scoala normală de fete din Beiuş (în 1923), pentru ca în octombrie 1924 să fie numit profesor de cântare bisericească la Academia de Teologie din Oradea. $\mathrm{La}$ internatul aceleiaşi Teologii, mama - Hermina - îndeplinea funcția de econoamă.

Tânărul Răzvan Givulescu a susținut bacalaureatul în iulie 1938 la liceul „E. Gojdu” din Oradea, pentru ca în octombrie al

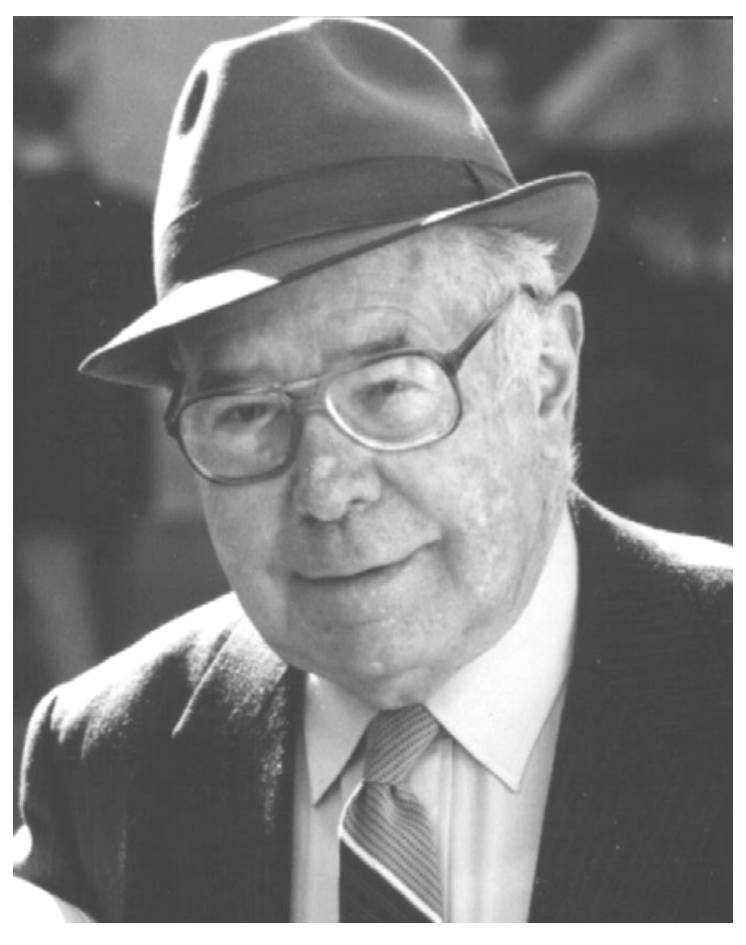
aceluiaşi an să-I găsim înscris în anul I al Universității „Regele Ferdinand I" din Cluj, Facultatea de Ştiințe, secția Ştiințe Naturale.

Din cauza izbucnirii celui de-al doilea război mondial, în august 1940 (după cedarea Ardealului de Nord), ajunge refugiat şi se reînscrie în anul III la Universitatea din Bucureşti (la aceeaşi facultate şi la aceeaşi secție). In iulie 1943 este declarat licențiat al Universității din Bucureşti, cu calificativul „foarte bine".

In 1944 este trimis pe frontul din Moldova şi după actul de la 23 august 1944 a fost mutat la mai multe unități militare, fiind - în cele din urmă demobilizat, în mai 1945.

La 1 septembrie 1945 a fost numit asistent suplinitor la Catedra de Geologie a Facultății de Ştiințe din Cluj. In 1950 a fost avansat la şef de lucrări, iar în 1952 a ocupat postul de conferențiar universitar, la aceeaşi catedră, unde a funcționat până în 1958.

În 1948 Răzvan Givulescu s-a căsătorit cu cea care avea să-i devină tovarăşă de viață: farmacista Virginia Bilciurescu, cu care a avut o unică fiică Mihaela. 
În mai 1949 şi-a susținut doctoratul, în comisia de specialitate fiind profesorii Dumitru lacob, Ion Al. Maxim şi Emil Pop. În 1957 i se tipăreşte un rezumat cuprinzător al tezei de doctorat „Cercetări geologice în Bazinul Borod”.

În septembrie 1958, Răzvan Givulescu a trebuit să părăsească Universitatea clujeană pentru „restrângere de activitate"(!). Au urmat angajări episodice (oficiant la poşta locală, tehnician de balastieră), până în octombrie 1961, când a fost numit conferențiar la Institutul Pedagogic din Baia Mare; la aceeaşi instituție a fost avansat profesor universitar (1969), iar în septembrie 1982 s-a pensionat (la cerere).

Din 1945 până în prezent, profesorul Răzvan Givulescu a dus o prodigioasă activitate de cercetare ştiințifică, publicând peste 325 de lucrări de specialitate, îndeosebi în domeniul Paleobotanicii terțiare. Mai departe vom menționa câteva din monografiile paleobotanice realizate de D-sa:

- „Flora pliocenă de la Cornițel, Oradea”, Edit. Academiei, Bucureşti, 1957;

- "Flora pliocenă de la Chiuzbaia, Maramureş”, Inst. Geologic, Memorii, 10, Bucureşti 1969 (în colaborare cu Virgil Ghiurcă);

- „Flora fosilă a Miocenului superior de la Chiuzbaia (județul Maramureş)", Edit. Academiei, Bucureşti, 1990;

- „Turbăriile fosile din Terțiarul României”, Edit. Carpatica, Cluj-Napoca, 1996;

- „Flora oligocenă superioară din Bazinul Petroşani”, Edit. Casa cărții de ştiință, Cluj-Napoca, 1996;

- „Istoria pădurilor fosile din Terțiarul Transilvaniei”, Edit. Carpatica, ClujNapoca, 1997;

- "Macro- şi microflora oligocenă de la Corneşti-Aghireş, România”, Edit. Carpatica, Cluj-Napoca, 1997 (în colaborare cu lustinian Petrescu şi Ovidiu Barbu);

- Flora mică ilustrată a Terțiarului din România”, Edit. Casa cărții de ştiință, Cluj-Napoca, 1999.

În mai 1993, ca o recunoaştere a prodigioasei munci de cercetare ştiințifică, a fost ales membru de onoare al Academiei Române.

De-a lungul anilor, profesorul Răzvan Givulescu a păstrat şi continuă să mențină relații colegiale cu personalul didactic al Departamentului de Geologie din cadrul Universității clujene. La sesiunile de comunicări a fost şi rămâne o prezență dinamică, ce nici la venerabila vârstă pe care o are nu cunoaşte răgaz. Catedra de Geologie-Paleontologie, în prezența Decanului Facultății de Biologie şi Geologie, i-a consacrat o reuniune de omagiere, finalizată prin volumul revistei Studia Universitatis Babeş-Bolyai - seria Geologia, pe care-I prefațăm. În numele colaboratorilor şi a întregului personal didactic şi de cerecetare din Departamentul de Geologie, sunt onorat să-i urez D-lui Profesor Răzvan Givulescu un sincer şi respectat LA MULȚI ANI!

Prof. Dr. lustinian PETRESCU 